\title{
Jakub Woziński
}

\section{Kapitalizm imperialny, a kapitalizm Kleinstaaterei}

\author{
$19 / 2015$ \\ Political Dialogues \\ DOI: http://dx.doi.org/10.12775/DP.2015.017
}

\begin{abstract}
The nineteenth century was the peak period for European monarchies which took control over most of the world. The then dominant capitalist system is sometimes regarded as a model, the implementation of which in the twentieth and twenty-first centuries was abandoned in favor of social democracy. However, in accordance with libertarian theory capitalism based on the existence of great empires is inferior to the 'early' capitalism of medieval Europe which was based on the governance of several hundred small states (Kleinstaaterei). Hoppe's theory of aggressiveness of liberal countries and passivity of socialist countries confirms that the nineteenthcentury capitalism was built on unstable foundations and therefore bound to collapse and give way to the twentiethcentury totalitarianisms.
\end{abstract}

Zgodnie $\mathrm{z}$ teza niektórych teoretyków kapitalizmu, takich jak Max Weber, czy też Włodzimierz Lenin, kapitalizm był ustrojem, który wykształcił się dopiero w XVIII i XIX wieku. $Z$ drugiej zaś strony wielu innych teoretyków zajmujących się tym zagadnienieniem przekonuje, iż kapitalizm pojawił się znacznie wcześniej. Autorzy monografii poświęconej historii biznesu w wiekach średnich, Edward S. Hunt oraz James M. Murray, uważaja, że Max Weber mylił się wskazując na protestanckie korzenie kapitalizmu oraz wskazuja, iż "duch kapitalizmu” był obecny już w Średniowieczu, wraz ze wszystkimi elementami składowymi tego, co uważa się powszechnie za kapitalizm (Hunt, Murray 2009, s. 242). Podobnego zdania co Hunt i Murray jest Hans-Hermann Hoppe, który wskazuje na źródła ustroju wolnorynkowego:

„(..) przednowoczesna Europa odznaczała się istnieniem bardzo konkurencyjnego, niemalże anarchistycznego systemu międzynarodowego, na który składało się mnóstwo małych rozmiarami państw oraz księstw feudalnych. To właśnie w tym kontekście narodził się kapitalizm". (Hoppe 1990, s. 77)

Istnienie tak sporych rozbieżności w ocenie tego, kiedy narodził się kapitalizm wymaga dokonania kluczowego dla dalszych rozważań ustalenia znaczenia samego terminu „kapitalizm”. Termin ten jest szczególnie kłopotliwy, ponieważ wymyślił go największy w historii wróg kapitalizmu, czyli Karol Marks.

Słownik języka polskiego definiuje kapitalizm jako „system społeczno-go- 
spodarczy oparty na prywatnej własności, wolnej konkurencji i rozwiniętej gospodarce rynkowej" (SJP). Definicję ta można uznać za poprawna, gdyż udaje jej się uniknąc marksistowskiego narzutu w postaci teorii o następujacych po sobie epokach w dziejach stosunków gospodarczo-spolecznych, w ramach której kapitalizm pojawia sie po feudalizmie oraz przed socjalizmem. Wskazując na własność prywatna oraz swobode konkurencji, wspomniana tu definicja słownikowa wydaje się ujmować istotę kapitalizmu jako systemu opartego na swobodzie działań.

Jak jednak przekonywał Murray N. Rothbard, sam termin „kapitalizm” wymaga jednak jeszcze dalszego uściślenia. Według niego należy bowiem odróżnić od siebie "kapitalizm wolnorynkowy" od „kapitalizmu państwowego”. Drugi z nich różni się od pierwszego tym, iż w ramach niego „jedna lub więcej grup wykorzystuje państwowy aparat sprawowania przymusu do akumulacji kapitału poprzez wywłaszczanie efektów pracy innych osób przy pomocy siły i przemocy" (Rothbard 1997, s 185).

Postulat zaprowadzenia czystego wolnorynkowego kapitalizmu stanowi kluczowy element filozofii libertariańskiej. "Czystość" tego rodzaju kapitalizmu nie oznacza oczywiście postulatu całkowitej eliminacji interakcji społecznych opartych na niedobrowolności. Filozofia libertariańska sugeruje jedynie, aby przypadkami wykroczeń przeciwko tzw. zasadzie nieinicjowania agresji zajmowały sie organy prywatne, a nie instytucja państwa. Tak sformułowana "czystość" kapitalizmu wolnorynkowego unika pospolitego zarzutu, iż libertarianie postuluja zaprowadzenie systemu społecznego pozbawionego agresji i przymusu. Agresji i przymusu nie da się nigdy zlikwidować, gdyż ich stosowanie wynika wprost $z$ istnienia wolnej ludzkiej woli. Libertarianizm postuluje wyłącznie, aby adminsitracja przypadkami niesłusznego zastosowania agresji i przymusu (tj. agresji wyprzedzajacej, nie stanowiącej odpowiedzi na żaden wcześniejszy akt agresji) zajmowały się siły prywatne, a nie państwo, które samo w sobie stanowi organizacje oparta na monopolu stosowania przymusu i agresji.

Nasze obecne rozważania skupia się jednak przede wszystkim na tzw. „kapitalizmie państwowym”, który na przestrzeni wieków przybierał rozmaite kształty, polegajace na większym lub mniejszym udziale państwa $\mathrm{w}$ systemie społecznych wymian i gospodarczych interakcji. Począwszy od starożytnych despotii, poprzez oświeceniowe monarchie, a skończywszy na współczesnych demokracjach, kapitalizm państwowy przechodził różnego rodzaju mutacje, które wpływały na zakres wolności żyjących w danym kontekście historycznym społeczeństwach.

Zaanonsowany w tytule tego artykułu „kapitalizm imperialny”, który występował w XIX wieku aż do wybuchu II wojny światowej, jest uważany za wzorcowy model systemu kapitalistycznego nie tylko przez jego wrogów, jak np. Karola Marksa, ale nawet przez jego zwolenników, jak choćby Ludwiga von Misesa. Autor "Ludzkiego działania” uważał, że kapitalizm XIX-wieczny stanowił tak naprawdę wynik procesu emancypacji z ograniczeń, które stanowiły przeszkodę $\mathrm{w}$ funkcjonowaniu gospodarki rynkowej od czasów Średniowiecza (Mises 2007, s. 229). W okresie funkcjonowania kapitalizmu imperialnego dokonała się wszak rewolucja przemysłowa, kapitalizacja giełd uległa skokowemu wzrostowi, zbudowano większość obecnie istniejacych linii kolejowych, swiat posługiwał się powszechnie standardem złota oraz 
dokonała się eksplozja demograficzna. Wszystkie te czynniki można by więc uznać niejako za „dowód rzeczowy” tezy, iż XIX-wieczny kapitalizm imperialny stanowił najbardziej produktywny i jednocześnie najbardziej sprzyjajacy rozwojowi cywilizacyjnemu okres w historii ludzkości.

W zestawieniu $z$ kapitalizmem imperialnym kapitalizm Kleinstaaterei z okresu Średniowiecza wydaje się posiadać o wiele mniej argumentów natrury materialnej. W Średniowieczu nie doszło przecież do ogromnej ekslpozji demograficznej ani spektaktularnej rewolucji przemysłowej, a giełdy kapitałowe dopiero zaczynały powstawać. Gdyby więc brać pod uwage same materialne skutki kapitalizmu $\mathrm{z}$ okresu wielkich imperiów oraz kapitalizmu średniowiecznego, musielibyśmy uznać, iż pierwszy z nich był zdecydowanie bliższy ideałowi kapitalizmu wolnorynkowego.

W tym momencie należy jednak zwrócić uwagę na podstawowa różnicę, jaka dzieliła Średniowiecze od XIX wieku. Jak wyliczył Charles Tilly, ok. 990 roku w Europie żyło ok. 80 milionów osób, które przynależały do ok. 500 państw, liczacych średnio mieszkańców. Tymczasem tuż przed I wojna światowa państw było już tylko 25. Oznacza to, że średnia liczba ludności państwa wzrosła ze 120 tysięcy w 990 roku do 9,3 mln w 1918 roku (Tilly 1990, s. 45). Kapitalizm Kleinstaaterei różniła więc od kapitalizmu imperialnego przede wszystkim ogromna konentracja władzy oraz wzrost siły państw i koncentracja władzy nad ludzkimi populacjami.

Jak zauważył Hans-Hermann Hoppe, czynnik koncentracji władzy oraz spadku liczby państw posiada ogromne znaczenie dla zakresu wolności w decydowaniu o własności prywatnej, czyli podstawowego czynnika kapitalizmu.
Aby wyjaśnić fukcjonowanie tego czynnika Hoppe przedstawił swoja teorię tzw. paradoksu wewnętrznego liberalizmu:

„Choć na pozór może się to wydawać paradoksalne, im bardziej liberalne wewnętrznie państwo, tym bardziej prawdopodobne jest to, iż zaangażuje się $\mathrm{w}$ agresję poza swoimi granicami. Wewnętrzny liberalizm czyni społeczeństwo bogatszym; z bogatszego społeczeństwa łatwiej uzyskać środki na bogatsze państwo; a bogatsze państwo oznacza coraz bardziej skuteczne ekspansjonistyczne wojny. (...)

Czerpiac $z$ bogactwa kapitalistycznych społeczeństw, słabe, liberalne państwa Europy Zachodniej stały się najbogatsze na świecie. To zaś bogactwo przyczyniło się do wybuchu imperialistycznych przedsięwzięć, które po raz pierwszy w historii uczyniły europejskie państwa prawdziwymi światowymi potęgami (Hoppe 1990, s. 76-77)."

Oznacza to, że XIX-wieczny kapitalizm imperialny oparty był nie na autentycznym poszanowaniu dla własności prywatnej i wolnej konkurencji, lecz na zaistniałym na rodzimym terytorium europejskich imperiów wewnętrznym liberalizmie. Takie państwa, jak Wielka Brytania, Francja, czy tė̇ Cesarstwo Niemieckie oferowały swoim obywatelom spore swobody gospodarcze, lecz jednocześnie prowadziły bezwzględną politykę podbojów w Azji, czy też Afryce. Wolność gopsodarcza i swoboda konkurencji na kontynencie europejskim została okupiona powstaniem wielkich mocarstw, które ograniczały wolność ludności krajów podbitych. O tym, jak wielkim złudzeniem kapitalizmu był kapitalizm XIX-wieczny świadczy ostatecznie najbardziej to, $z$ jaka łatwościa narody europejskie przyjęły w I połowie XX wieku program skrajnie etatystyczny, gdy świat przestał oferować możliwości dalszych imperial- 
nych podbojów. Kapitalizm XIX-wieczny był bowiem źródłowo nie kapitalizmem wolnorynkowym, lecz kapitalizmem panstwowym, w którym wewnętrzny liberalizm oparty był na państwie jako narzędziu ciagłych podbojów przynoszacych korzyści ekonomiczne.

W odróżnieniu od kapitalizmu imperialnego, kapitalizm średniowieczny (który będzie dalej nazywany „kapitalizmem Kleinstaaterei" - zgodnie $z$ funkcjonujacym w literaturze przedmiotu niemieckojęzycznym określeniem okresu w dziejach, gdy zamiast centralnie zarzadzanych imperiów istniały setki niezależnych, małych państewek) wykazywał się o wiele większym zakresem wolności decydowania o własności prywatnej oraz większą swoboda konkurencji, ponieważ jego fundament stanowiła konkurencja małych organizmów państwowych. Sredniowiecze praktycznie nie znało pojęcia imperium, ponieważ Święte Cesarstwo Rzymskie do czasów panowania dynastii Habsburgów nigdy nie powierzyło władzy centralnej takich kompetencji, które przekreślałyby podstawowe przymioty władzy lokalnej. W pozostałych krajach Europy wielkie, silnie scentralizowane państwa także powstały dopiero w okresie Odrodzenia lub nawet Oświecenia (te dwa wielkie nurty kulturowe można zreszta odczytywać jako wielkie dążenia do poszerzenia kompetencji państwa).

Jak już wspomniano, kapitalizm Kleinstaaterei nie może się poszczycić tak spektakularnymi sukcesami, jak eksplozja demograficzna, czy też rewolucja przemysłowa, lecz w okresie tym dokonało się przecież wiele istotnych osiagnięć cywilizacyjnych. To właśnie w Średniowieczu powstały uniwersytety, szpitale, zakładano tysiące wsi i miast, a architektura osiagnęła poziom rozwoju, który w poprzednich wiekach był nieosiagalny. Ostatecznie jednak prawdzi- wym probierzem tego, czy dany system społeczny spełnia zasadę dobra wspólnego nie sa jednak materialne wytwory, lecz wolność w decydowaniu o własności prywatnej, która on oferuje. Ponadto, spektakularny rozwój cywilizacyjny nie dokonał się w XIX wieku wszędzie, lecz przede wszystkim na macierzystych terytoriach, które stanowiły dla imperiów punkt wyjścia w ich własnym rozwoju terytorialnym.

Zestawienie ze soba kapitalizmu imperialnego $z$ kapitalizmem Kleinstaaterei jest bardzo pomocne w wykazaniu sprzeczności idei klasycznego liberalizmu, która święciła największe triumfy właśnie w XIX wieku oraz była oparta na przekonaniu o możliwości zbudowania trwałego systemu kapitalizmu państwowego. Parafrazujac marksistowskie stwierdzenie, iż byt poprzedza świadomość, można nawet stwierdzić, iż klasyczny liberalizm Adama Smitha powstał jako teoretyczne uzsadnienie dla stanu faktycznego, jakim był wewnętrzny liberalizm gospodarczy Zjednczonego Królestwa Wielkiej Brytanii i Irlandii - najpoteżniejszego państwa na świecie. Państwo to stanowiło doskonała egzemplifikacje teorii Hoppego o paradoksie wewnętrznego liberalizmu: dajac swoim obywatelom niespotykane wcześniej wolności gospodarcze, jednocześnie drastycznie ograniczało liczbę państw i konkurencję między nimi w zakresie stanowienia prawa, czy też podatków. Jednocześnie wolności gospodarcze obywateli imperium były możliwe jedynie dzięki potędze państwa, które najczęściej przy pomocy potężnej armii (w przypadku Zjednoczonego Królestwa floty), co stanowiło odwrócenie sytuacji ze Średniowiecza, gdy wolności obywatelskie oparte były na słabej władzy państwa.

Współcześni epigoni klasycznego liberalizmu, jak choćby konserwatyw- 
ni liberałowie, nie dostrzegaja związku między liczba i rozmiarami państw a zakresem wolności i dlatego postuluja wciąz niemożliwą do zaistnienia strukturę państwa stojącego na straży własności prywatnej. Tymczasem konstrukcja teoretyczna państwa rozumianego jako „nocny stróż” zawiera w sobie sprzeczność oraz nie znajduje żadnej historycznej egzemplifikacji. Aby państwo mogło ograniczyć swoje kompetencje do jakkolwiek rozumianego minimum, musi wszak najpierw ograniczyć swoje rozmiary. Jeśli przyjąć definicję państwa jako organizacji sprawujacej monopol na sprawowanie środków przymusu na danym terytorium, wówczas należy zdać sobie sprawę $z$ tego, że panowanie danego państwa na dużym terytorium pociaga za soba proporcjonalne do rozmiarów państwa wysiłki na rzecz zachowania pełnej kontroli. Im większy obszar podporządkowany danemu państwu, tym więcej środków finansowych jest mu potrzebnych do podtrzymywania pełnionej przez siebie roli podmiotu sprawującego monopol w zakresie usług bezpieczeństwa.

Co więcej, koncepcja państwa minimalnego bardzo rzadko bywa wiazana z postulatem demontażu i podziału obecnych struktur państwowych na mniejsze jednostki. Brak tej perspektywy sprawia, iż koncepcja ta postuluje sprzeczna ideę państwa maksymalnego terytorialnie, lecz jednocześnie minimalnego administracyjnie. Jak już wspomniano, tego typu konstrukt nigdy nie istniał; historia zna co najwyżej przykłady obszarów terytorialnych, na których władza państwa była słaba, lecz jedynie dzięki wielości małych organizmów państwowych, jak np. w średniowiecznej Europie.

Przedstawione wnioski powinny także pobudzić do refleksji nad tym, czy postulowany przez libertarian ustrój społeczny powinien w ogóle nosić nazwę „kapitalizm”, skoro tak bardzo obarczony jest on marksistowska wizją dziejów oraz powszechnym wyobrażeniem na temat kapitalizmu jako systemu społecznego, w którym państwo współtworzy wielkie przedsięwzięcia gospodarcze oparte na giełdzie, rynku obligacji, czy też skartelizowanym przez bank centralny systemie bankowym. Być może zaniechanie posługiwania się przez teoretyków libertarianizmu słowa „kapitalizm” pozwoliłby im w sposób bardziej precyzyjny przedstawić swoja własna propozycję teoretyczna, tak bardzo różniąca się od propozycji klasycznego liberalizmu.

$\mathrm{W}$ istocie bowiem system społeczny, który postuluje teoria libertariańska, wymaga jedynie zaistnienia sieci dobrowolnych wymian międzyosobowych oraz istnienia prywatnego systemu zapewniania usług prawnych i ochronnych. Biorąc pod uwage kluczowość oparcia systemu funkcjonowania społeczeństwa na dobrowolnych wymianach oraz dążność libertarianizmu do zapewnienia pewnego ładu wolnego od instytucjonalnych wad społeczeństwa rządzonego przez państwo, bardziej poprawne byłoby stosowanie innych terminów, np. ładu bezpaństwowego lub społeczeństwa libertariańskiego.

Warto także zauważyć, że słowo „kapitał" bywa najczęściej źle rozumiane. W teorii marksistowskiej kapitał przynależał do kapitalistów, czyli osób, które wyzyskiwały proletariuszy, odbierajac im wypracowana wartość dodana $z$ produkcji dóbr materialnych. Tymczasem w ramach ekonomii kapitał bywa często rozumiany odmiennie. Według Ludwiga von Misesa „kapitał to suma pieniędzy równa ekwiwalentowi pieniężnemu wszystkich aktywów pomniejszonemu o ekwiwalent pieniężny wszystkich zobowiązań, ustalona na określony dzień działalno- 


\section{Dialogi Polityczne/Political Dialogues}

ści określonego przedsiębiorstwa (Mises 2007, s. 227). Mises dopuszczał także metaforyczne określenie mianem kapitału zasobów dostępnych jednostkom także przed nastaniem gospodarki opartej na kalkulacji pieniężnej, lecz zasadniczo jego koncepcja kapitału zdecydowanie różni się od koncepcji marksistowskiej oraz tej, która stosuje się powszechnie. Zgodnie $\mathrm{z}$ misesowskim rozumieniem kapitału kapitalistami powinni zostać nazwani m.in. także włoscy kupcy z XIII i XIV wieku, gdyż jako pierwsi zaczęli stosować zasady podwójnego księgowania. Niemniej jednak, współcześni im kupcy niemieccy, którzy zasady podwójnego księgowania nie stosowali, nie powinni być - zdaniem Misesa - określani mianem kapitalistów, choć przecież ich przedsięwzięcia były praktycznie identyczne $z$ przedsięwzięciami gospodarczymi kupców włoskich. Fakt ten pokazuje, jak wiele trudności sprawia samo pojęcie kapitału, który ostatecznie odnosi się przede wszystkim do przedsiębiorczych warstw społeczeństwa, które zawsze stanowia pewna jego mniejszość. Termin kapitalizm nie tylko więc narzuca marksistowską siatkę pojęć, ale także nie jest dostatecznie ostrym pojęciem $\mathrm{w}$ ramach samej ekonomii, aby służyć do rzetelnego opisu tak złożonego zjawiska, jak systemy społeczne.

Wykazywana wyższość kapitalizmu Kleinstaaterei nad kapitalizmem imperialnym nie kończy jednak dyskusji na temat kapitalizmu jako takiego. Kapitalizm Kleinstaaterei nie był przecież czystym kapitalizmem wolnorynkowym, lecz także pewnego rodzaju kapitalizmem państwowym. Wydaje się bowiem, że najbardziej „kapitalistycznym” ustrojem społecznym był ustrój, który w Europie obowiazywał jeszcze przed nastaniem chrześcijańskich państw. Zachowane źródła prawa wielu ludów barbarzyńskich ukazuja nam Europe jako kontynent, na którym nieobecne były państwa, a jednocześnie której ludność cieszyła się wieloma swobodami. Najlepiej opisane w tym zakresie sa takie kraje, jak Irlandia (Feehan-Fitzgerald 2015) czy też Islandia (Friedman 1995, s. 145). W istocie jednak w całej Europie funkcjonowały spoleczeństwa $z$ niepaństwowym systemami zapewniania usług bezpieczeństwa oraz prawnych. Nie realizowały one wszystkich postulatów współczesnej teorii libertariańskiej, gdyż zamiast konkurencyjnych podmiotów stanowiących usługi prawne i bezpieczeństwa rolę tę pełniły zgromadzenia plemienne, zwane w świecie germańskim thingami, zaś u Słowian wiecami. Charakterystyka funkcjonowania zgromadzeń plemiennych zapewniała jednak jednostkom o wiele większa swobodę $\mathrm{w}$ dziedzinie decydowania o swojej własności niż w przypadku państw epoki Średniowiecza oraz późniejszych.

Podsumowując, system społeczny Europy $z$ okresu Średniowiecza w zdecydowanie większym stopniu spełnial kryteria „kapitalizmu wolnorynkowego" (inaczej: społeczeństwa libertariańskiego ładu bezpaństwowego) ponieważ oparty był na słabości i wielości państw, które dysponowały mniejszymi zasobami ludnościowymi i terytorialnymi niż państwa współczesne. Wolność gospodarcza i osobista osób żyjacych w tej epoce znalazła przełożenie na wszechstronny rozwój cywilizacyjny. W odróżnieniu od kapitalizmu Kleinstaaterei, kapitalizm XIX-wieczny (kapitalizm imperialny) był systemem, w którym gwałtowny wzrost wielu czynników uważanych powszechnie za wskaźniki rozwoju cywilizacyjnego został okupiony bezprecedensowym w historii Europy wzrostem potęgi państw. Funkcjonujące w XIX wieku imperia dzięki zyskom kapitałowym $z$ podbojów kolonialnych oraz na kontynencie 
europejskim potrafiły zrekompensować sobie niższe wpływy do budżetu $z$ tytułu podatków pobieranych od ludności swojego pierwotnego terytorium. Tak funkcjonujacy system był jednak skazany na porażkę, gdyż jego motorem napędowym nie była faktyczna i powszechna wolność gospodarcza, lecz jej kondensacja na macierzystych terytoriach imperiów. Europejskie centra finansowe stanowily jednocześnie ośrodki władzy imperialnej, przy pomocy której państwa europejskie podporządkowały sobie większą część świata, eksportując swój kapitał.

Biorac pod uwage powyższe rozważania, system kapitalizmu wolnorynkowego wymaga przede wszystkim rozpadu istniejacych struktur państwowych na jak najmniejsze jednostki, które poprzez wzajemna konkurencję przyczyniaja się do osłabiania samej instytucji państwa. Dażenie do kapitalizmu wolnorynkowego wymaga więc nie tyle dokonywania zmian $\mathrm{w}$ na poziomie obecnie istniejacych państw, lecz działań na rzecz ich fragmentaryzacji. Brak zrozumienia tej prawidłowości stanowi o słabości wielu propozycji teoretycznych postulujacych zaprowadzenie wolności gospodarczej przy zachowaniu istniejacych struktur państwowych.

\section{Bibilografia:}

Feehan-Fitzgerald, F. (2015), Prawo prywatne na szmaragdowej wyspie, tekst udostępniony $\mathrm{w}$ serwisie internetowym Instytu Misesa (http://mises. pl/blog/2013/03/17/ prawo-prywatne-na-szmaragdowej-wyspie/). (dostęp 13.10.2015)

Friedman, D. (1995), The Machinery of Freedom, Open Court, Chicago.

Hoppe, H.H. (1990), Banking, Nation States and International Politics: A So- ciological Reconstruction of the Present Economic Order, The Review of Austrian Economics, Vol. 4, 1990.

Hunt E.S., Murray, J.M. (2009), A History of Business in Medieval Europe, 12001550, Cambridge University Press.

von Mises, L. (2007), Ludzkie działanie, Instytut Misesa, Warszawa.

Rothbard, M.N., The Logic of Action Two: Applications and Criticism from the Austrian School. Glos, UK: Edward Elgar Publishing Ltd..

Tilly, C. (1990), Coercion, Capital and European States, $A D$ 990-1990,Basil Blackwell Inc., Oxford.

Internetowa wersja Słownika Języka Polskiego PWN, dostępna pod adresem: http://sjp.pwn.pl/sjp/kapitalizm; 2562818 (dostęp 7/09/2015). 